\title{
Midgley, Mary, What Is Philosophy For?'
}

\section{Jovito V. Cariño}

$\mathrm{T}$ The book What Is Philosophy For? is Mary Midgley's final published work. It came out in 2018, the same year she passed on, or just a year shy of what would have been her $100^{\text {th }}$ birthday. She was born in London on September 13, 1919. Midgley was, for me, a belated but precious find. I had the distinct privilege of meeting and listening to her in person when I attended the International Society for MacIntyrean Enquiry (ISME) held at the University of Nottingham, UK sometime July 2012. Prior to that, Midgley was not even a name to me (due in large measure to the limited reach of my philosophic reading). Like any average researcher, I used to think of English philosophy or any English philosopher for that matter as either analytic or masculine (logic, mathematics, and analysis are traditionally recognized as male provinces of the human brain). My naiveté had me consider either as a rarity or an oddity an English intellectual who forays into Continental philosophic questions. Obviously, I failed to reckon that the likes of R.G. Collingwood, Terry Eagleton, and Simon Critchley were English and so were woman thinkers like Iris Murdoch, Philippa Foot, and Elizabeth Anscombe who were not just as compelling but also as intellectually gifted. Midgley belonged to this strand of English thought, a tradition that stretched as far back to Lord Shaftesbury, David Hume, and, to a degree, Adam Smith of The Theory of Moral Sentiments. She counted herself as one among those who were sympathetic with the so-called "big questions" frowned upon by the analytic movement. Simon Critchley, for example, reported how Jacques Derrida almost missed his honorary doctoral degree from the University of Cambridge after its academic community questioned whether there was genuine philosophy in Derrida's body of works. ${ }^{2}$

As her culminating work, What Is Philosophy For? weaves together the main themes Midgley explored and navigated in her previous projects. In a way, with or without her conscious intention, it provides a general tour of her philosophic itinerary spanning a lifetime of intellectual labor from Beast and

${ }^{1}$ London: Bloomsbury Academic, 2018, 223pp.

2 Simon Critchley, Continental Philosophy: A Very Short Introduction (Oxford: Oxford University Press, 2001), 34.

(c) 2020 Jovito V. Cariño

https://www.kritike.org/journal/issue 27/carino december2020.pdf

ISSN 1908-7330

(cc) $\mathrm{BY}-\mathrm{NC}-\mathrm{ND}$ 
Man (1978), Animals and Why They Matter (1983), Evolution as Religion (1985) and Wisdom, Information, and Wonder: What Is Knowledge For? (1989), to the more recent vintage represented by the likes of Science as Salvation: A Modern Myth and Its Meaning (1992), The Ethical Primate: Humans, Freedom, and Morality (1994), and Utopias, Dolphins, and Computer (1996). Consequently, what veritably counts as her swan song also serves as an overture which highlights the contours of her fundamental claims on such problems touching on human nature, ethics, freedom, scientism, materialism, quantum physics, digital technology, and yes, the function of philosophy, among others. The collection of topics covered by the book may appear daunting but due to Midgley's lucid, almost crystalline prose, not to mention her characteristic natural way with words, reading it easily becomes a refreshing experience of philosophic reeducation. In describing what she thought of philosophy, for example, she wrote: “...I have often suggested that philosophy is best understood as a form of plumbing. It's the way in which we service the deep infrastructure of our lives - the patterns that are taken for granted because they have not really been questioned." 3 In another part, where she dismissed the reductive physicalism of the Vienna Circle and Rudolf Carnap, she argued her point by saying: "If 'physical entities' means only ones that can be described in the language of physics, then everyday life simply contains hardly any physical entities at all. Physics never speaks of loaves and apples, pen and paper, men and women, bricks and mortar. It always speaks, far more abstractly, of solids and liquids, protons and electrons, vacuums and black holes." 4

Midgley's notion of philosophy is guided by her agonistic ontological vision which puts her in direct opposition to the segmentary proclivity of the modern worldviews. She attributes the spread of the latter to the "increasing specialization of our age - the growing tendency of educators to supply more and more separate examinable qualifications for everything rather than putting things together intelligibly."5 While she does not discount the plurality of perspectives surrounding a problem, she believes nonetheless that they are not completely estranged so as not to find any connection among them. Hence, for her, philosophy's task is "...to find ways of bringing the two sides together." ${ }^{\prime}$ More than just an epistemic stance, this intellectual attitude also suggests Midgley's overall ethical view. This is shown in her critique of the Vienna Circle's physicalism and BF Skinner's behaviorism. Against the latter theories, Midgley argues against the lopsided focus of those theories on

${ }^{3}$ Mary Midgley, What Is Philosophy For? (London: Bloomsbury Academic, 2018), 64.

${ }^{4}$ Ibid., 152-153.

${ }^{5}$ Ibid., 192.

${ }^{6}$ Ibid., 194.

(C) 2020 Jovito V. Cariño

https://www.kritike.org/journal/issue 27/carino december2020.pdf

ISSN 1908-7330 


\section{WHAT IS PHILOSOPHY FOR?}

the outside dimension of the human lifeworld at the expense of the inner subjective spirit. As she wrote, "...the inner, subjective point of view is every bit as natural and necessary for human thought as the outside objective one...you can't have the outside of the teapot without the inside." 7

Given the obvious slant of the title, the whole trajectory of the book comes to the reader almost gratuitously. In choosing to formulate the title in this manner, Midgley runs the risk of getting her portrait of philosophy read as functional, utilitarian, or even apologetic. Thanks, however, to the masterful construction of her arguments, she succeeds not only in avoiding this but also in offering an engaging second look at "what is philosophy for" by confronting head-on the views she was arguing against. If only for this, the book is a must-read for apprentices of philosophic practice, for the jaded who presume either to have known enough philosophy or have known philosophy enough, and lastly, for those who do not think philosophy is worth knowing. Those who wish to reacquaint themselves with the question "What is philosophy for?" might also find this volume inviting. The simplest question is often the most elusive, to paraphrase Heidegger. Midgley's book shows us why and how this will remain a perennial predicament.

Department of Philosophy, University of Santo Tomas, Philippines

\section{References}

Critchley, Simon, Continental Philosophy: A Very Short Introduction (Oxford: Oxford University Press, 2001).

Midgley, Mary, What Is Philosophy For? (London: Bloomsbury Academic, 2018).

${ }^{7}$ Ibid., 200.

(c) 2020 Jovito V. Cariño

https://www.kritike.org/journal/issue 27/carino december2020.pdf

ISSN 1908-7330

(c) BY-NC-ND 